\title{
Temperature-induced oviposition in the brachyuran crab Cancer setosus along a latitudinal cline: Aquaria experiments and analysis of field-data
}

\author{
Sönke Fischer ${ }^{\mathrm{a}, *}$, Sven Thatje ${ }^{\mathrm{b}}$ \\ ${ }^{a}$ Alfred Wegener Institute for Polar and Marine Research, Am Handelshafen 12, 27570 Bremerhaven, Germany \\ ${ }^{\mathrm{b}}$ National Oceanography Centre, Southampton, School of Ocean and Earth Science, University of Southampton, European Way, \\ Southampton, SO14 3ZH, United Kingdom
}

Received 26 July 2007; received in revised form 1 November 2007; accepted 19 January 2008

\begin{abstract}
Ovigerous females of Cancer setosus are present year-round throughout most of its wide range along the Peruvian/Chilean Pacific coast $\left(2^{\circ} \mathrm{S}-46^{\circ} \mathrm{S}\right)$. However, their number of egg-masses produced per year remains speculative and as such has neither been considered in latitudinal comparisons of reproduction, nor for its fisheries management. In order to reveal the effect of temperature on egg-mass production and eggdevelopment, female $C$. setosus were held in through-flow aquaria under natural seasonal temperature conditions (16-23 $\left.{ }^{\circ} \mathrm{C}\right)$ in Antofagasta $\left(23^{\circ} \mathrm{S}\right)$, Northern Chile $\left(05 / 2005-03 / 2006 ; 10\right.$ months), and at three constant temperatures $\left(12,16,19{ }^{\circ} \mathrm{C}\right)$ in Puerto Montt $\left(41^{\circ} \mathrm{S}\right)$, Central Southern Chile (09/2006-02/2007; 5 months). Female crabs uniformly produced up to 3 viable egg-masses within $41 / 2$ months in Antofagasta and in Puerto Montt (at $19{ }^{\circ} \mathrm{C}$ ). The second egg-mass was observed 62.5 days $( \pm 7.6 ; N=7)$ after the oviposition of the first clutch and a third egg-mass followed 73.5 days $( \pm 12.5 ; N=11)$ later in Antofagasta (at $\left.16-23^{\circ} \mathrm{C}\right)$. Comparably, a second oviposition took place 64.4 days $( \pm 9.8$, $N=5)$ after the first clutch and a third, 67.0 days $( \pm 2.8, N=2)$, thereafter, at $19{ }^{\circ} \mathrm{C}$ in Puerto Montt. At the two lower temperatures $(16$ and $\left.12{ }^{\circ} \mathrm{C}\right)$ in Puerto Montt a second egg-mass was extruded after 82.8 days $( \pm 28.9 ; N=4)$ and 137 days $(N=1)$, respectively. The duration of eggdevelopment from oviposition until larval hatching decreased from 65 days at $12.5^{\circ} \mathrm{C}$ to 22.7 days at the observed upper temperature threshold of $22^{\circ} \mathrm{C}$. Based on the derived relationship between temperature and the duration of egg-development $\left(y=239.3175 \mathrm{e}^{-0.107 x} ; N=21, r^{2}=0.83\right)$ and data on monthly percentages of ovigerous females from field studies, the annual number of egg-masses of $C$. setosus was calculated. This analysis revealed an annual output of about one egg-mass close to the species northern and southern distributional limits in Casma $\left(9^{\circ} \mathrm{S}\right)$ and Ancud $\left(43^{\circ} \mathrm{S}\right)$, respectively, while at Coquimbo $\left(29^{\circ} \mathrm{S}\right)$ about two and in Concepción $\left(36^{\circ} \mathrm{S}\right)$ more than 3 egg-masses are produced per year. (C) 2008 Elsevier B.V. All rights reserved.
\end{abstract}

Keywords: C. magister; C. pagurus; El Niño; Humboldt Current; Temperature adaptation

\section{Introduction}

Most of the 24 extant species of cancrid crabs (Nations, 1975, 1979; Carvacho, 1989) are found in cold temperate and boreal waters of the Pacific and Atlantic Oceans (MacKay, 1943). Their reproductive cycles follow seasonal changes in temperature and food availability in these regions. Typically, one annual egg-mass is produced in autumn, incubated throughout the winter-period, and larvae are released at the time of the spring plankton peak when food and growth

\footnotetext{
* Corresponding author. Tel.: +49 4714831 1643; fax: +49 47148311149 .
}

E-mail address: soenke.fischer@awi.de (S. Fischer). conditions are favourable (Krouse, 1972; Hines, 1991; Shields, 1991; Stone and O'Clair, 2002; Park et al., 2007). Exceptions to this general pattern are C. antennarius and C. anthonyi, which are able to produce multiple egg-masses per year in the Southern California current at the North American Pacific coast, where they find relatively stable conditions year-round (Carroll, 1982; Shields et al., 1991).

Reproductive parameters vary not only between species, but also latitudinally. The size of maturity in C. irroratus and C. pagurus (Shields, 1991, and citations therein), larvae size in C. magister (Shirley et al., 1987), and egg-size, and fecundity in C. setosus follow a latitudinal cline (Brante et al., 2003). Such knowledge on the effects of seasonal and latitudinal changes in 
temperature on reproductive traits is crucial to understanding large-scale distributional patterns of species.

The hairy edible crab Cancer setosus (Molina 1782; synonymous C. polyodon Poeppig 1836) is one of the key predators in a variety of shallow water habitats ( $<25 \mathrm{~m}$ depths $)$ in the Humboldt Current ecosystem (Wolff and Cerda, 1992; Cerda and Wolff, 1993; Ortiz and Wolff, 2002a,b; Jesse and Stotz, 2003; León and Stotz, 2004). This species is caught by an artisanal diving and trapping fishery throughout its wide latitudinal range from Guayaquil in Ecuador $\left(2^{\circ} \mathrm{S}, 079^{\circ} \mathrm{W}\right)$ to the Peninsula of Taitao in Southern Chile $\left(46^{\circ} \mathrm{S}, 075^{\circ} \mathrm{W}\right)(\mathrm{Garth}, 1959)$. A collapse of this fishery has been reported in years that follow strong El Niño events when the upper temperature threshold for survival of C. setosus has been exceeded (Arntz et al., 1988; Arntz and Fahrbach, 1991; Lang, 2000). Egg-bearing C. setosus and females having ripe gonads are found year-round at various locations between Central Chile and Central Peru (Gutiérrez and Zúñiga, 1976; Veaz, 1981; Talledo and Ishiyama, 1988; Wolff and Soto, 1992; Moya, 1995; Jesse, 2001). Nevertheless, it remains speculative if $C$. setosus possesses an extended reproductive period or if individual females actually produce more than a single egg-mass annually.

The aim of this study was to estimate the possible occurrence of multiple annual ovipositions and the duration of interbrood periods for females from Antofagasta (Northern Chile; $23^{\circ} \mathrm{S}$, $70^{\circ} \mathrm{W}$ ) and Puerto Montt (Central Southern Chile; $41^{\circ} \mathrm{S}, 73^{\circ} \mathrm{W}$; see Fig. 1). Furthermore, the duration of egg-development of $C$. setosus was observed under the natural seasonal temperature regime in Antofagasta $\left(16-23{ }^{\circ} \mathrm{C}\right)$ and for the local ambient temperature in Puerto Montt $\left(\sim 12.5^{\circ} \mathrm{C}\right)$. Based on the derived relationship between temperature and the duration of eggdevelopment, the annual number of egg-masses of $C$. setosus was calculated from the literature on the percentage of eggbearing females and temperature (Giese, 1959; Wenner et al., 1991) for the locations Casma, Coquimbo (La Herradura Bay and Tongoy Bay), Concepción, and Ancud (see Fig. 1).

\section{Material and methods}

\subsection{Capture and rearing of crabs}

Mature female C. setosus were caught by divers at 5-10 m water depth at different sites around Antofagasta, Northern Chile $\left(23^{\circ} \mathrm{S}, 70^{\circ} \mathrm{W}\right.$; capture between $05 / 2005$ and $\left.10 / 2005\right)$ and in Carelmapu, Central Southern Chile $\left(41^{\circ} \mathrm{S}, 73^{\circ} \mathrm{W}\right.$; capture between $09 / 2006$ and 11/2006). The crabs from Northern Chile were held in captivity for up to 10 months in the Aquaculture Institute of the "Universidad de Antofagasta" and the specimen from Central Southern Chile for up to 5 months in the "Universidad Austral de Chile" in Puerto Montt.

\subsubsection{Antofagasta}

In Antofagasta, ovigerous and non-ovigerous crabs were placed in two 3200-1 aquaria in groups of 12 specimens each. These aquaria constantly had a high flow through of fresh seawater, which ensured cleanliness and maintained the water temperature at a comparable level as found in Antofagasta
Bay (Fig. 2). Illumination took place by natural day light. To allow for burying activity of the crabs, the aquaria were equipped with sand-filled boxes and with stones and PVCtubes to provide additional shelter. Two large males were given to one of the aquaria for 3 months to make observations on mating activity. Females that moulted in the absence of males, where separated from their co-specimen until their new exoskeleton was hardened to avoid cannibalism in the softshell state. Dead crabs were replaced by new specimens from the field.

\subsubsection{Puerto Montt}

In Puerto Montt, solely females with undifferentiated blastula-state eggs were used, which was checked microscopically. Up to nine specimen where held at a time in one of three 500-1 aquaria, with constant temperatures of $12( \pm 0.3), 16( \pm 0.5)$ and $19( \pm 0.3){ }^{\circ} \mathrm{C}$, respectively. Crabs in the 16 and $19{ }^{\circ} \mathrm{C}$ aquaria, where acclimatized over 2 to 3 days to this temperatures by gradually raising the temperature from $12^{\circ} \mathrm{C}$. However, for hygienic reasons the closed aquaria did not contain sand-filled boxes, but only large rocks to provide shelter. Light was kept at a 12:12 day-night cycle.

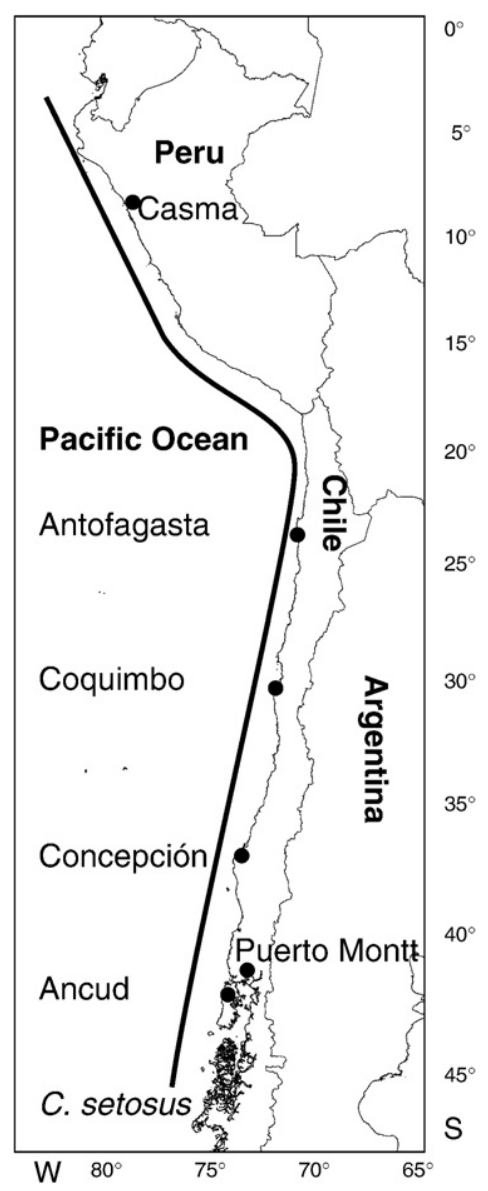

Fig. 1. Distributional range of C. setosus along the Latin-American Pacific Coast (after Garth, 1959), the experimental sites Antofagasta and Puerto Montt and sites considered for literature review (Casma, Coquimbo, Concepción, Ancud); map modified after PanMap (Diepenbroek et al., 2000). 


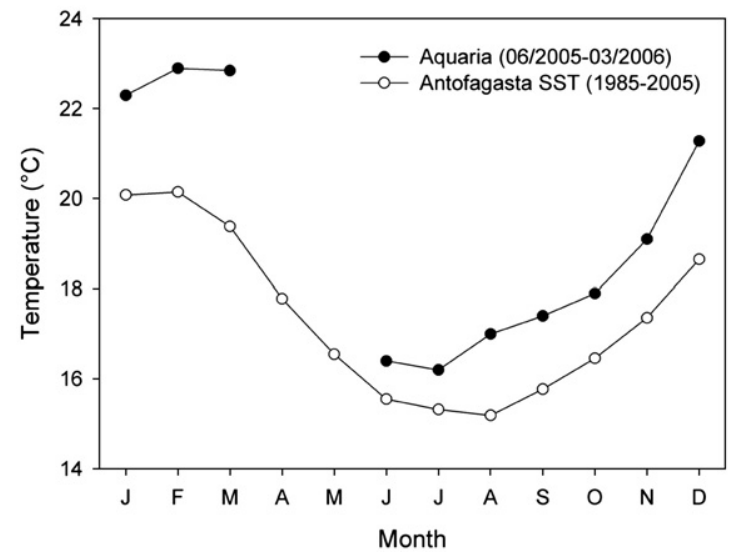

Fig. 2. Antofagasta/Northern Chile: Temperature throughout the experiment (06/ 2005-03/2006) and mean monthly SST (1985-2005; CENDHOC).

In both locations the crabs were fed ad libitum with living mussels Perumytilus purpuratus; aquaria were cleaned and water temperature was recorded daily.

\subsection{Measurements and observations}

Each crab was individually marked with a small plastic tag glued onto the carapace and the width of the carapace $(\mathrm{CW})$ was measured with callipers to the nearest millimetre including the 10th anterolateral spine. The crabs were checked twice daily for the occurrence of moulting, mating, oviposition, and hatching of larvae. After oviposition, the developmental success of the egg-mass was monitored until hatching. Eggs were taken with fine forceps from the border of the egg-mass every 2 to 3 days and were assigned microscopically to one of four successive developmental stages:

I. Blastula - no yolk used; 1 to 2 days after oviposition

II. Gastrula $-25 \%$ of the yolk used, still no eyes visible

III. Eye-placode - eyes are visible as a kidney-shaped small dark spot, but still no chromatophores present and no heartbeat

IV. Pre-hatching - all yolk utilized, eyes completely roundish, chromatophores well developed, heart beats vigorously and embryo moves inside the egg-shell; 1 to 2 days before larvae hatching (stages modified after Baeza and Fernández, 2002).

Eggs were identified as dead by the presence of discolorations in the first three developmental stages and by the lack of a heartbeat in the pre-hatching stage.

\subsection{Annual number of egg-masses along latitude}

The annual number of egg-masses was calculated for populations from Casma, Coquimbo (La Herradura Bay; Tongoy Bay), Concepción and Ancud (for locations see Fig. 1) based on the literature on the monthly percentage of ovigerous females $\left(N_{i}\right)$, the mean length of a month of 30.4 days and the duration of egg- development (days) for the mean monthly sea surface temperature at the respective location $\left(d_{\mathrm{ie}}\right)$ :

Annual_egg-masses $=\sum_{i=1}^{n \leq 12} \frac{N_{i}(\%) \times 30.4}{d_{i e}}$

\section{Results}

Female C. setosus were held in captivity for up to 10 months in Antofagasta, Northern Chile, and for up to 5 months in Puerto Montt, Central Southern Chile. Their reproduction was presented as the sequence of moulting/mating, oviposition, embryo incubation, and interbrood periods. Ovigerous females ranged in carapace width from 79 to $158 \mathrm{~mm}$ in Antofagasta and from 107 to $140 \mathrm{~mm}$ in Puerto Montt.

\subsection{Moult, oviposition, and interbrood periods}

\subsubsection{Antofagasta (natural seasonal temperature conditions of $\left.16-23{ }^{\circ} \mathrm{C}\right)$}

Thirteen females moulted successfully in captivity, of which 5 mated with a male crab. Males started the pre-copulatory embrace about a week before the females' ecdysis took place and extended their mate-guarding for 2-3 days post-copula. The average increment in carapace width per moult was $12 \%$ $( \pm 5 ; N=13)$.

Oviposition took place 2 months after moulting (62.1 days \pm 10 ; $N=9$ ), when female crabs buried in the sand to form an incubation chamber with their abdomen. Eggs were extruded stepwise over several hours into this incubation chamber, allowing a part of the egg-mass to attach to the pleopod-hairs, before the abdomen was further opened and more eggs were extruded. At the end of oviposition females kneaded the new egg-mass with the dactyli of their pereiopods and showed abdominal flapping. After eclosion of larvae, females produced up to two more viable egg-masses without moulting. The second egg-mass was observed 62.5 days $( \pm 7.6 ; N=7)$ after the oviposition of the first clutch and a third egg-mass was laid another 73.5 days $( \pm 12.5 ; N=11)$ later. The interbrood periods took 29.7 days $( \pm 13.1 ; N=17)$ and 47.8 days $( \pm 18.2 ; N=6)$, calculated as the duration from larvae hatching to the oviposition of the following egg-masses two and three, respectively. Females moulted again about 2 months after larval release $(59.3 \pm 18.8$; $N=9$ ) (Table 1).

\subsubsection{Puerto Montt $\left(12,16,19{ }^{\circ} \mathrm{C}\right)$}

Two months after the first oviposition a second egg-mass was produced (64.4 days $\pm 9.8, N=5$ ) and a third egg-mass followed 67.0 days $( \pm 2.8 ; N=2)$ later at $19{ }^{\circ} \mathrm{C}( \pm 0.3)$ in Puerto Montt (Table 1). The interbrood periods took one month (30.8 days \pm 3.0 ; $N=4)$ between the first and the second egg-mass. At $16^{\circ} \mathrm{C}( \pm 0.5)$ four females produced a second egg-mass about 82.8 days $( \pm 28.9)$ after the oviposition of the first one. A single female moulted 66 days after larval hatching. At $12{ }^{\circ} \mathrm{C}( \pm 0.3)$ one female produced a second egg-mass about 137 days after the oviposition of the first and two more showed ripe ovaries when the experiment was ended (81 days after oviposition). 
Table 1

Temporal sequence of reproductive events in cancrids: moult, oviposition, interbrood periods and annual number of egg-masses

\begin{tabular}{|c|c|c|c|c|c|c|c|c|}
\hline \multirow[t]{2}{*}{ Species } & \multirow[t]{2}{*}{$T\left({ }^{\circ} \mathrm{C}\right)$} & \multirow[t]{2}{*}{ Moult-oviposition (days) } & \multicolumn{2}{|c|}{$\begin{array}{l}\text { Oviposition-oviposition } \\
\text { (days) }\end{array}$} & \multicolumn{2}{|c|}{$\begin{array}{l}\text { Interbrood period } \\
\text { (days) }\end{array}$} & \multirow[t]{2}{*}{$\begin{array}{l}\text { Larvae } \\
\text { hatching-moult (days) }\end{array}$} & \multirow[t]{2}{*}{ Egg-masses/year } \\
\hline & & & $1-2$ & $2-3$ & $1-2$ & $2-3$ & & \\
\hline C. antennarius & $12 \pm 2^{1}$ & $77(N=1)^{1}$ & & & & & & $\begin{array}{l}\text { Ovigerous } \\
\text { year-round }^{2}\end{array}$ \\
\hline C. anthonyi & $13.5 \pm 1.6^{3}$ & & & & $\begin{array}{l}41.9 \pm 11.5 \\
(N=78)^{3}\end{array}$ & & & $\begin{array}{l}\text { Ovigerous } \\
\text { year-round }{ }^{2} \text {;up } \\
\text { to } 3^{\text {a3 }}\end{array}$ \\
\hline C. magister & & $90^{3} ; 163(81-391 ; N=14)^{5}$ & & & & & & $\leq 1^{4}$ \\
\hline C. pagurus & & $120^{3}$ & & & & & & $\leq 1^{3}$ \\
\hline C. gracilis & $6.9-13.4^{6}$ & & & & & & & $2^{\text {a }}(2 . \text { very small })^{6}$ \\
\hline C. productus & $6.9-13.4^{6}$ & & & & & & & $2^{a}(2 . \text { very small })^{6}$ \\
\hline C. setosus & & & & & & & & $0.9-3.6^{\mathrm{b}}$ \\
\hline Puerto Montt & $12 \pm 0.3$ & & $137(N=1)$ & & & & & \\
\hline Puerto Montt & $16 \pm 0.5$ & & $82.8 \pm 28.9(N=4)$ & & & & $66(N=1)$ & \\
\hline Puerto Montt & $19 \pm 0.3$ & & $64.4 \pm 9.8(N=5)$ & $\begin{array}{l}67.0 \pm 2.8 \\
(N=2)\end{array}$ & $\begin{array}{l}30.8 \pm 3.0 \\
(N=4)\end{array}$ & & & $\begin{array}{l}\text { up to } 3 \text { in } \\
124.0 \text { days } \pm 2.8^{\text {a }} \\
(N=2)\end{array}$ \\
\hline Antofagasta & $16-23$ & $62.1 \pm 10.0(N=9)$ & $62.5 \pm 7.6(N=7)$ & $\begin{array}{l}73.5 \pm 12.5 \\
(N=11)\end{array}$ & $\begin{array}{l}29.7 \pm 13.1 \\
(N=17)\end{array}$ & $\begin{array}{l}47.8 \pm 18.2 \\
(N=6)\end{array}$ & $\begin{array}{l}59.3 \pm 18.8 \\
(N=9)\end{array}$ & $\begin{array}{l}\text { up to } 3 \text { in } \\
133.6 \text { days } \pm 6.6^{\text {a }} \\
(N=7)\end{array}$ \\
\hline
\end{tabular}

(1) Caroll (1982); (2) Reilly (1987); (3) Shields et al. (1991) and studies therein; (4) Swiney et al. (2003); (5) Ebert et al. (1983); (6) Knudsen (1964).

a Laboratory conditions.

b Analysis of field-data on percentage of ovigerous females.

\subsection{Egg-development and survival}

Throughout the study period 44 egg-masses were produced in Antofagasta, however not all egg-masses successfully completed development. Within the temperature range of $16-22{ }^{\circ} \mathrm{C}$ larvae hatched in 21 out of 34 egg-masses (62\%). Egg-mass mortality within this temperature range occurred in advanced developmental stages (eye-placode to pre-hatching) (Fig. 3). Females continued to produce egg-masses in the austral-summer $(N=10)$ when temperatures ranged between 22 and $24{ }^{\circ} \mathrm{C}$. However, at these temperatures, all eggs either failed to connect to the setae on

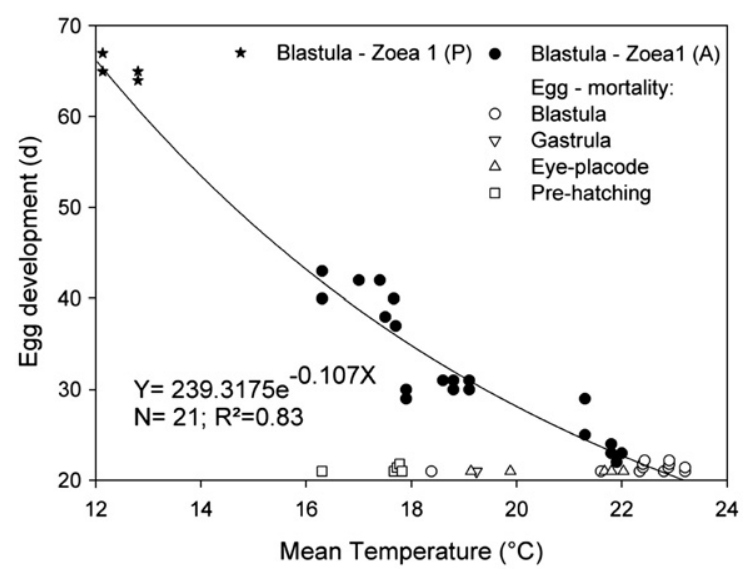

Fig. 3. Duration of egg-development of C. setosus from oviposition to larvae hatching in Antofagasta (A) (filled dots). Throughout the experiment in Antofagasta 44 egg-masses were produced of which 23 died, before larvae hatched (unfilled symbols, showing the developmental stage when egg-mass mortality occurred; not scaled to the $y$-axis). The duration of egg-development of C. setosus in Puerto Montt $(\mathrm{P})$ at $12.1-12.8{ }^{\circ} \mathrm{C}$ is indicated by asterisks $(n=5)$. the pleopods at oviposition, or died within few days afterwards. Egg-development in Antofagasta took 43.2 days from oviposition to hatching of larvae at $16^{\circ} \mathrm{C}$ in austral-winter and was shortened to 22.7 days at a mean temperature of $22^{\circ} \mathrm{C}$ in summer (Fig. 3). The effect of temperature $(x)$ on the duration of egg incubation until larvae hatching $(y)$ is described by an exponential decay function: $y=239.3175 \mathrm{e}^{-0.0107 x}\left(r^{2}=0.83 ; N=21\right)$. Egg-development at $12.5^{\circ} \mathrm{C}$ in Puerto Montt took 65 days $( \pm 1.2 ; N=5)$, which is similar to the calculated duration of 62.8 days for this temperature (based on the formula from Antofagasta). The relation between temperature and duration of egg-development was then used to calculate the annual number of egg-masses along latitude from field studies (see Section 3.3).

\subsection{Seasonal reproductive cycle and annual number of egg- masses along latitude (south to north)}

Ovigerous C. setosus are found in Ancud ( $\left.41^{\circ} \mathrm{S}\right)$ from australwinter until early austral-summer (Pool et al., 1998), reaching a maxima from August to October, which coincides with the spring temperature rise (Fig. 4). Based on the percentage of eggbearing females and the duration of egg incubation at the mean monthly SST $\left({ }^{\circ} \mathrm{C}\right)$ an annual output of 0.9 egg-masses per female was calculated for this location. Five degrees of latitude further north in Concepción $\left(36^{\circ} \mathrm{S}\right)$, reproduction takes place yearround (Veaz, 1981) (Fig. 4), which leads to an annual output of 3.6 egg-masses per female. In Tongoy Bay and La Herradura Bay, the former located south and the later north of Coquimbo $\left(29^{\circ} \mathrm{S}\right), 2.1$ and 1.8 annual egg-masses are produced, respectively (Soto, 1990; Jesse, 2001) (Fig. 4). With the exception of the hot summer months, reproduction also takes place round the year in Casma (9S) (Moya, 1995) (Fig. 4), but due to the low 

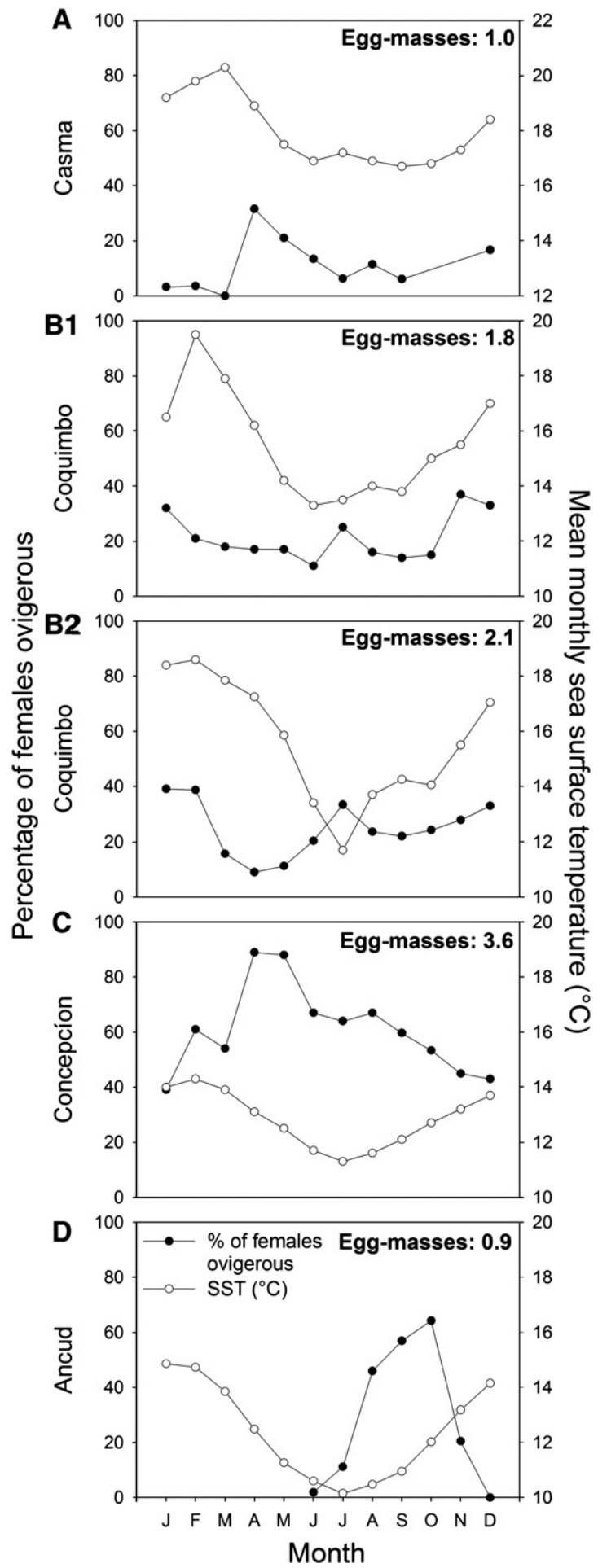

Fig. 4. Monthly percentage of ovigerous female C. setosus and SST $\left({ }^{\circ} \mathrm{C}\right)$ along latitude and calculated annual egg-masses: (A) Casma, Guaynuna Bay, $9^{\circ} \mathrm{S}, 12 /$ 1994-09/1995 (Moya, 1995); SST 01/2002-09/2006; Acuacultura y Pesca S.A.C. pers. com.; (B) Coquimbo: (1) La Herradura Bay, 295, 02/1987-01/1988 (Soto, 1990); SST—-same study; (2) Tongoy Bay, 30º S, 06/1996-05/1997 (Jesse, 2001); SST 06/1996-05/1997 (CENDHOC); (C) Concepción, Concepción Bay \& San Vincent Bay, 36 ${ }^{\circ}$ S, 11/1980-08/1981(Veaz, 1981); SST 01/1983-01/2003 (CENDHOC); (D) Ancud, Yuste Bay $41^{\circ} \mathrm{S}, 06 / 1997-05 / 1998$ (Pool et al., 1998); SST 01/1999-12/2005 (CENDHOC). overall percentage of egg-bearing females only one annual eggmass is produced at this location.

\section{Discussion}

\subsection{Reproductive potential - aquaria experiments}

Contrary to most other cancrid crabs who have but one annual egg-mass (Shields, 1991), C. setosus produced up to 3 eggmasses within $41 / 2$ months (at $16-23{ }^{\circ} \mathrm{C}$ in Antofagasta and at $19^{\circ} \mathrm{C}$ in Puerto Montt), which is the highest known reproductive output within this genus (Table 1.). These observations were highly comparable in Antofagasta and Puerto Montt, showing that the potential to have multiple ovipositions is not genetically constrained to crabs from Northern Chile. Interestingly, all crabs in Antofagasta needed about the same time span of 2 months from moult to an initial oviposition, thereafter to a following oviposition and finally from larvae hatching to moult (Table 1.). Based on these results, it seems reasonable to argue that the energetic costs of moulting and oviposition are comparable.

Multiple ovipositions were also observed at 12 and $16^{\circ} \mathrm{C}$ in Puerto Montt, however due to the slowing down of metabolism at lower temperatures, more time was required to obtain sufficient energy for a second oviposition. To meet the energy demand of egg-production, ovigerous females were not quiescent as reported for C. pagurus and C. magister (Howard, 1982; Stone and O'Clair, 2002), but active and constantly feeding. Furthermore, this continuous reproduction of $C$. setosus is enabled by the storage of sperm in the spermatheca after mating, which serves to inseminate at least three egg-masses without an intervening moult. Such a reduced moult-frequency of mature females has the advantage that mortality in the soft-shell state is avoided and energy effectively can be directed towards egg-production. The price of this energetic investment in offspring is a reduction of female growth efficiency by half, compared to male crabs (Wolff and Cerda, 1992). Sperm stored in the spermatheca stays viable for at least 2 1/2 years and serves in C. magister and C. pagurus to inseminate more than one egg-mass, which however are produced over consecutive years (Pearson, 1908; Edwards, 1966; Bennett, 1974; Hankin et al., 1989). In these two species, but not for $C$. setosus (this study), "sperm plugs" protrude after mating for some time from the female gonopores, where they are easy to be recognised and thus help to resolve the mating history of crabs from field studies (Edwards, 1966; Haefner, 1977; Oh and Hankin, 2004). In C. setosus, sperm can even be retained via moults as shown by females who moulted in the absence of male crabs and afterwards produced up to two viable egg-masses.

\subsection{Duration and success of egg-development}

Temperature is the main factor determining the duration and success of (crustacean) egg-development (Wear, 1974). Egg incubation was accelerated by the seasonal temperature rise in Antofagasta until a thermal limit of $22^{\circ} \mathrm{C}$, when larvae hatched three times earlier than at $12{ }^{\circ} \mathrm{C}$ in Puerto Montt $\left(\mathrm{Q}_{10} \sim 3\right)$. The overall temperature-related duration of egg-development was comparable to that of C. antennarius and C. anthonyi (Carroll, 
Table 2

Duration of cancrid egg-development and temperature

\begin{tabular}{llll}
\hline Species & $T\left({ }^{\circ} \mathrm{C}\right)$ & Egg-development (days) & Reference \\
\hline C. antennarius & $12 \pm 2$ & $49-56$ & $\begin{array}{l}\text { Carroll (1982) } \\
\text { C. anthonyi }\end{array}$ \\
& 10 & 55 & $\begin{array}{l}\text { Shields and Kuris } \\
(1988)\end{array}$ \\
& 15 & 42 & \\
C. magister & $20^{\mathrm{a}}$ & 27 & Wild (1980, 1983a,b) \\
& 9.4 & 123 & \\
C. pagurus & 12.5 & 72 & Wear (1974) \\
C. setosus & $16.7^{\mathrm{a}}$ & 64 & Present study \\
Puerto Montt & 12.5 & 65.0 & \\
Antofagasta & 16 & 43.2 & \\
Antofagasta & 20 & 28.2 & \\
Antofagasta & $22^{\mathrm{a}}$ & 22.7 & \\
\hline
\end{tabular}

${ }^{\mathrm{a}}$ Upper temperature threshold of egg-development.

1982; Shields and Kuris, 1988), who also have similar-sized eggs (Hines, 1991; Shields et al., 1991; this study), but faster than for the larger eggs of C. pagurus and C. magister (Wear, 1974; Wild, 1983a) (see Table 2).

Eggs produced at temperatures above $22{ }^{\circ} \mathrm{C}$ failed to connect to the female pleopods at oviposition (Fig. 3), which occurred most likely due to a temperature limitation within the complex process of egg-attachment (Saigusa et al., 2002). Such a failure of egg-attachment at high temperatures has also been reported for the American lobster Homarus americanus (Waddy and Aiken, 1995). However, at lower temperatures $\left(16-22^{\circ} \mathrm{C}\right)$ about $40 \%$ of the egg-masses died before larvae hatching occurred, which might be attributed to an oxygen limitation inside the egg-mass (Brante et al., 2003). Oxygen demand of developing eggs increases with ontogenetic progress and scales with temperature (Naylor et al., 1999; Baeza and Fernández, 2002), which may explain why eggmass mortality occurred at progressively earlier developmental stages with seasonal temperature rise (Fig. 3).

$22{ }^{\circ} \mathrm{C}$ presents the highest reported temperature for successful cancrid egg-development and for $C$. magister larvae-hatching success is already greatly reduced at $16-17{ }^{\circ} \mathrm{C}$ (Wild, 1983a). A further source of substantial egg mortality of $C$. magister are infestations by nemertean egg-predators Carcinomertes errans (Wickham, 1979; Kuris, 1991), which however, were only found infrequently and in low densities in egg-masses of C. setosus.

\subsection{Annual number of egg-masses along latitude}

Favourable temperatures year-round, which are subject solely to moderate seasonal oscillation (Urban, 1994), combined with the high food availability in the shallow water benthic ecosystem (Wolff and Soto, 1992) create ideal conditions for continuous reproduction of $C$. setosus from Central Southern to Northern Chile. This is reflected in an annual output of about 2 egg-masses in Coquimbo (both La Herradura Bay and Tongoy Bay) and more than 3 egg-masses in Concepcíon (Fig. 4). A comparable reproductive potential within the cancrids is only known for the yellow rock crab $C$. anthonyi from the Southern California Current (Shields et al., 1991).
Nevertheless, C. setosus only produces about one annual eggmass close to its southern and northern extremes of distribution (Ancud, Casma) (Fig. 4), most likely due to the high relative metabolic cost of life nearby the species lower and upper temperature threshold (for reviews see Clarke, 1987, 2003; Pörtner, 2001). Likewise, C. magister fails to acquire sufficient energy to produce one egg-mass every year at their northern distributional range in Southern Alaska (Swiney and Shirley, 2001; Swiney et al., 2003), which is the normal reproductive output throughout most of this species range.

\section{Conclusions}

The annual number of egg-masses produced by C. setosus is primarily dependent on temperature when food is not limited, and presents a key reproductive parameter, which has to be considered for comparisons of reproductive output and effort along latitude.

\section{Acknowledgements}

We like to thank Marcelo Oliva for his support and friendship, which made the experiments at the Instituto de Acuicultura of the Universidad de Antofagasta possible. Sincere thanks also to Kurt Paschke, Juan Pablo Cumillaf, and Alejandro Riedemann of the Instituto de Acuicultura at the Universidad Austral de Chile, Puerto Montt, for providing rearing facilities and constant help. Experiments in Puerto Montt were supported by a DAADscholarship to the first author. This study was conducted in the frame of the EU-project CENSOR (Climate variability and El Niño Southern Oscillation: Implications for natural coastal resources and management, Contract 511071). This is CENSOR publication number 0121. [SS]

\section{References}

Arntz, W.E., Fahrbach, E., 1991. El Niño - Klimaexperiment der Natur: physikalische Ursachen und biologische Folgen. Birkhäuser, Berlin.

Arntz, W.E., Valdivia, E., Zeballos, J., 1988. Impact of El Niño 1982-83 on the commercially exploited invertebrates (mariscos) of the Peruvian shore. Meeresforschung 32, 3-22.

Baeza, J.A., Fernández, M., 2002. Active brood care in Cancer setosus (Crustacea: Decapoda): the relationship between female behaviour, embryo oxygen consumption and the cost of brooding. Funct. Ecol. 16, 241-251.

Bennett, D.B., 1974. Growth of the edible crab (Cancer pagurus L.) of SouthWest England. J. Mar. Biol. Assoc. U.K. 54, 803-823.

Brante, A., Fernández, M., Eckerle, L., Mark, F., Pörtner, H.-O., 2003 Reproductive investment in the crab Cancer setosus along a latitudinal cline: egg production, embryo losses and embryo ventilation. Mar. Ecol. Prog. Ser. 251, 221-232.

Carroll, J.S., 1982. Seasonal abundance, size composition, and growth of rock crab, Cancer antennarius Stimpson, offCentral California. J. Crustac. Biol. 2, 549-561.

Carvacho, A., 1989. Cancer johngarthi, n. sp. and Cancer porteri (Bell) (Crustacea, Decapoda): comparisons and hypothesis. Proc. Biol. Soc. Wash. 102, 613-619.

CENDHOC, Centro Nacional de Datos Hidrográficos y Oceanográficos de Chile, http://www.shoa.cl/cendoc-jsp/index.jsp.

Cerda, G., Wolff, M., 1993. Feeding ecology of the crab Cancer polyodon in La Herradura Bay, Northern Chile. II Food spectrum and prey consumption. Mar. Ecol. Prog. Ser. 100, 119-125.

Clarke, A., 1987. Temperature, latitude and reproductive effort. Mar. Ecol. Prog. Ser. 38, 89-99. 
Clarke, A., 2003. Costs and consequences of evolutionary temperature adaptation. Trends Ecol. Evol. 18, 573-581.

Diepenbroek, M., Grobe, H., Sieger, R., 2000. PanMap. http://www.pangaea.de/ Software/PanMap.

Ebert, E.E., Haseltine, A.W., Houk, J.L., Kelly, R.O., 1983. Laboratory cultivation of Dungeness crab, Cancer magister. In: Wild, P.W., Tasto, R.N. (Eds.), Life history, environment, and mariculture studies of the Dungeness crab, Cancer magister, with emphasis on the Central California fishery resource. Calif. Fish. Game Fish Bull, pp. 259-309.

Edwards, E., 1966. Mating behaviour in the European edible crab (Cancer pagurus L.). Crustaceana 10, 23-30.

Garth, J., 1959. Reports of the Lund University Chile expedition 1948-1949. The Crustacea Decapoda Brachyura of Chile. Lunds. Univ. Arsskr., vol. 53, pp. $1-130$.

Giese, A.C., 1959. Comparative physiology: annual reproductive cycles of marine invertebrates. Annu. Rev. Physiol. 21, 547-576.

Gutiérrez, J., Zúñiga, O., 1976. Cancer setosus Molina en la Bahía de Mejillones del Sur (Crustacea, Decapoda, Brachyura). Rev. Biol. Mar. Dep. Oceanol. Univ. Chile, vol. 16, pp. 1-25.

Haefner Jr., P.A., 1977. Aspects of the biology of the Jonah crab, Cancer borealis Stimpson, 1859 in the Mid-Atlantic Bight. J. Nat. Hist. 11, 303-320.

Hankin, D.G., Diamond, N., Mohr, M.S., Ianelli, J., 1989. Growth and reproductive dynamics of adult female Dungeness crabs (Cancer magister) in Northern California. J. Cons. - Cons. Int. Explor. Mer. 46, 94-108.

Hines, A.H., 1991. Fecundity and reproductive output in nine species of Cancer crabs (Crustacea, Brachyura, Cancridae). Can. J. Fish. Aquat. Sci. 48, 267-275.

Howard, A.E., 1982. The distribution and behaviour of ovigerous edible crab (Cancer pagurus) and consequent sampling bias. J. Cons. - Cons. Int. Explor. Mer. 40, 259-261.

Jesse, S., 2001. Comparative ecology of sympatric brachyuran crab species in the shallow subtidal of the Pacific Coast of North Chile and their importance for the artisanal fishery in Puerto Aldea. ZMT contribution: 12, ZMT, Bremen, pp. 1-113.

Jesse, S., Stotz, W., 2003. Spatio-temporal distribution patterns of the crab assemblage in the shallow subtidal of the North Chilean Pacific Coast Crustaceana 75, 1161-1200.

Knudsen, J.W., 1964. Observations on the reproductive cycles of the common Brachyura and Anomura of Puget Sound, Washington. Pac. Sci. 18, 3-33.

Krouse, J.S., 1972. Some life history aspects of the rock crab, Cancer irroratus, in the Gulf of Maine. J. Fish. Res. Board Can. 29, 1479-1482.

Kuris, A.M., 1991. A review of patterns and causes of crustacean brood mortality. In: Wenner, A., Kuris, A. (Eds.), Crustacean egg production, Crustacean Issues, vol. 7. A.A. Balkema, Rotterdam, pp. 117-141.

Lang, M., 2000. Distribution, population structure and feeding behaviour of the decapods Cancer polyodon and Cancer porteri in the Independencia Bay, Peru. Diplomarbeit. Universität Bremen, Bremen.

León, R.I., Stotz, W.B., 2004. Diet and prey selection dynamics of Cancer polyodon in three different habitat types in Tongoy Bay, Chile. J. Mar. Biol. Assoc. U.K. 84, 751-756.

MacKay, D.C.G., 1943. Temperature and the world distribution of crabs of the genus Cancer. Ecology 24, 113-115.

Moya, J.F.M., 1995. Biología reproductiva y crecimiento del "Cangrejo peluda" Cancer setosus MOLINA (Crustacea: Decapoda) en la Bahía de Guaynuna Casma (Peru), Deciembre 1994-Septiembre 1995. Licenciatura. Universidad Nacional de Trujilllo, Trujillo.

Nations, J.D., 1975. The genus Cancer (Crustacea: Brachyura): systematics, biogeography and fossil record. Bull. Los Angel. Cty. Mus. Nat. Hist. 23, 1-104.

Nations, J.D., 1979. The genus Cancer and its distribution in space and time. Bull. Biol. Soc. Wash 3, 153-187.

Naylor, J.K., Taylor, E.W., Bennett, D.B., 1999. Oxygen uptake of developing eggs of Cancer pagurus (Crustacea: Decapoda: Cancridae) and consequent behaviour of the ovigerous females. J. Mar. Biol. Assoc. U.K. 79, $305-315$.

Oh, S.J., Hankin, D.G., 2004. The sperm plug is a reliable indicator of mating success in female Dungeness crabs, Cancer magister. J. Crustac. Biol. 24, 314-326.

Ortiz, M., Wolff, M., 2002a. Application of loop analysis to benthic systems in Northern Chile for the elaboration of sustainable management strategies. Mar. Ecol. Prog. Ser. 242, 15-27.
Ortiz, M., Wolff, M., 2002b. Trophic models of four benthic communities in Tongoy Bay (Chile): comparative analysis and preliminary assessment of management strategies. J. Exp. Mar. Biol. Ecol. 268, 205-235.

Park, W., Douglas, D.C., Shirley, T.C., 2007. North to Alaska: evidence for conveyor belt transport of Dungeness crab larvae along the West Coast of the United States and Canada. Limnol. Oceanogr. 52, 248-256.

Pearson, J., 1908. XVI. Cancer. L.M.B.C. Memoirs on Typical British Marine Plants \& Animals. Williams \& Norgate, London.

Pool, H., Montenegro, C., Canales, C., Barahona, N., Vicencio, C., 1998. Analisis de la pesquería de jaiba en la X region: FIP-IT/96-35. Instituto de Fomento Pesquero, Valparaíso, pp. 1-219.

Pörtner, H.O., 2001. Climate change and temperature-dependent biogeography: oxygen limitation of thermal tolerance in animals. Naturwissenschaften 88 , 137-146.

Reilly, P.N., 1987. Population studies on rock crab Cancer antennarius, yellow crab, $C$. anthonyi, and Kellet's whelk, Kelletia kellettii, in the vicinity of Little Cojo Bay, Santa Barbara County, California. Calif. Fish Game 73, $88-98$.

Saigusa, M., Terajima, M., Yamamoto, M., 2002. Structure, formation, mechanical properties, and disposal of the embryo attachment system of an estuarine crab, Sesarma haematocheir. Biol. Bull. 203, 289-306.

Shields, J.D., 1991. Reproductive ecology and fecundity of Cancer crabs. In: Wenner, A., Kuris, A. (Eds.), Crustacean Egg Production, Crustacean Issues, vol. 7. A.A. Balkema, Rotterdam, pp. 193-213.

Shields, J.D., Kuris, A.M., 1988. An in vitro analysis of egg mortality in Cancer anthonyi: the role of symbionts and temperature. Biol. Bull. 174, 267-276.

Shields, J.D., Okazaki, R.K., Kuris, A.M., 1991. Fecundity and the reproductive potential of the yellow rock crab Cancer anthonyi. Fish. Bull. 89, 299-305.

Shirley, S.M., Shirley, T.C., Rice, S.D., 1987. Latitudinal variation in the Dungeness crab, Cancer magister: zoeal morphology explained by incubation temperature. Mar. Biol. 95, 371-376.

Soto, M.A., 1990. Dinamica poblacional de Cancer setosus Molina (Decapoda, Brachyura) en un sector de la Bahía la Herradura, bajo un impacto de extraccion continua. Licenciatura. Universidad Católica del Norte, Coquimbo.

Stone, R.P., O'Clair, C.E., 2002. Behaviour of female Dungeness crabs, Cancer magister, in a glacial Southeast Alaska estuary: homing, broodingsite fidelity, seasonal movements and habitat use. J. Crustac. Biol. 22, 481-492.

Swiney, K.M., Shirley, T.C., 2001. Gonad development of Southeastern Alaskan Dungeness crab, Cancer magister, under laboratory conditions. J. Crustac. Biol. 21, 897-904.

Swiney, K.M., Shirley, T.C., Taggert, S.J., O'Clair, C.E., 2003. Dungeness crab, Cancer magister, do not extrude eggs annually in Southeastern Alaska: an in situ study. J. Crustac. Biol. 23, 280-288.

Talledo, C., Ishiyama, V., 1988. Reproductive cycle of the female Cancer setosus from the littoral of Lima, Peru. In: Salzwedel, H., Landa, A. (Eds.), Recursos y dinámica del ecosistema de afloramiento peruano Bol. Inst. Mar. Peru-Callao, Vol extraordinario, pp. 147-151.

Urban, H.-J., 1994. Upper temperature tolerance of ten bivalve species of Peru and Chile related to El Niño. Mar. Ecol. Prog. Ser. 107, 139-145.

Veaz, A.J.P., 1981. Estudio biológico-pesquero preliminar de la jaiva peluda (C. setosus MOLINA, 1782) en Bahía Concepción (P. Tumbes $36^{\circ} 37^{\prime} \mathrm{S}$, $73^{\circ} 05^{\prime} 0$ ) y Bahía San Vicente (Reque $36^{\circ} 45^{\prime} \mathrm{S}, 73^{\circ} 12^{\prime} 0$ ). Licenciatura. Universidad de Concepción, Concepción.

Waddy, S.L., Aiken, D.E., 1995. Temperature regulation of reproduction in female American lobsters (Homarus americanus). ICES mar. Sci. Symp. 199, 54-60.

Wear, R.G., 1974. Incubation in British decapod crustacea, and the effects of temperature on the rate and success of embryonic development. J. Mar. Biol. Assoc. U.K. 54, 745-762.

Wenner, A.M., Dugan, J.E., Wells, H., 1991. Estimating egg production in multibrooding populations. In: Wenner, A., Kuris, A. (Eds.), Crustacean Egg Production, Crustacean Issues, vol. 7. A.A. Balkema, Rotterdam, pp. $333-355$.

Wickham, D.E., 1979. Predation by the nemertean Carcinonemertes errans on eggs of the Dungeness crab Cancer magister. Mar. Biol. 55, 45-53.

Wild, P.W., 1980. Effects of Seawater Temperature on Spawning, Egg Development, Hatching Success and Population Fluctuations on the Dungeness crab, Cancer magister. CALCOFI Rep., vol. 21, pp. 115-120. 
Wild, P.W., 1983a. The influence of seawater temperature on spawning, egg development, and hatching success of the Dungeness crab, Cancer magister. Calif. Dep. Fish. Game, Fish. Bull. 172, 197-214.

Wild, P.W., 1983b. Comparison of ovary development in Dungeness crabs Cancer magister in Central and Northern California. Fish Bull. 172, 189-196.
Wolff, M., Cerda, G., 1992. Feeding ecology of the crab Cancer polyodon in La Herradura Bay, Northern Chile. I. Feeding chronology, food intake, and gross growth and ecological efficiency. Mar. Ecol. Prog. Ser. 89, 213-219. Wolff, M., Soto, M., 1992. Population dynamics of Cancer polyodon in La Herradura Bay, Northern Chile. Mar. Ecol. Prog. Ser. 85, 69-81. 